REVIEW PAPER

\title{
Human impacts on the environment and wildlife in California's past: Lessons from California archaeology
}

\section{JULIA R. PRINCE-BUITENHUYS ${ }^{1 *}$, COLLEEN M. CHEVERKO², ERIC J. BARTELINK ${ }^{3}$, VERONICA WUNDERLICH ${ }^{4}$, AND KRISTINA CRAWFORD $^{5}$}

${ }^{1}$ California Department of Transportation, North Region Environmental, District 3, 703 B Street, Marysville, CA 95901, USA

${ }^{2}$ Edward Via College of Osteopathic Medicine - Louisiana Campus, 4408 Bon Aire Drive, Monroe, LA 71203

${ }^{3}$ California State University, Chico, Department of Anthropology, 400 West 1st Street, Chico, CA 95929, USA

${ }^{4}$ California Department of Water Resources, Division of Integrated Science and Engineering, 3500 Industrial Blvd, West Sacramento, CA 95691, USA

${ }^{5}$ University of Nevada, Reno, Department of Anthropology, 1664 N Virginia Street, Reno, NV 89557, USA

*Corresponding Author: Julia.prince-buitenhuys@dot.ca.gov

The long history of human-animal interactions in California prior to European contact is frequently not considered when setting ecological baselines and, by consequence, when planning conservation and management expectations and strategies for native species. This article reviews archaeological perspectives that explore the relationship between human niche construction, plant and wildlife populations, and human health in pre-European contact Central California, with an emphasis on the Central Valley and Delta, the surrounding foothills, and the San Francisco Bay Area. A summary of the archaeological record for Central California is provided, along with how niche construction and related evolutionary based models have been used in prehistoric California. Examples of the influences of human niche construction on flora, fauna, and human health from the archaeological and ethnographic record are then discussed. This information is tied to modern wildlife research and management practices that would serve contemporary fish and wildlife management given that human influences on species "natural" habitats and ecological baselines extends much further into the past than current ecological baselines and wildlife management strategies traditionally recognize. 
Key words: archaeology, Central Valley, Delta, ecological baselines, environmental management, health, niche construction, San Francisco Bay, traditional management practices

Conservation practices in California have long recognized how human-wildlife interactions affect the ability of species populations to thrive or decline. For instance, the survival of the giant garter snake (Thamnophis gigas), a highly aquatic wetland-marshland dependent snake endemic to the Central Valley of California, is influenced directly by land use practices. As the Central Valley was transformed from native wetland to a patchwork of urban, suburban, commercial, industrial, and agricultural uses, giant garter snake populations also changed. In areas such as the Tulare Basin, where water diversion and development of agricultural crops such as cotton, corn, and grains eliminated the wetland habitat, the species was locally extirpated. In the San Joaquin Valley, much of the wetland habitat was similarly replaced with a variety of agricultural crops such as cotton and almonds, along with urban and industrial development, resulting in severe population decline and fragmentation (USFWS 2017). In the Sacramento Valley, similar land use changes have occurred, but unlike the San Joaquin Valley or Tulare Basin, rice cultivation represents approximately $20 \%$ of the regional agriculture production. Here, snake populations have persisted with a less severe overall decline than in the southern parts of the snake's range. The cultivation of rice, often adjacent to patches of remaining marsh/wetland habitat, provides a suitable, albeit less ideal, habitat that provides the summer water regime required by this mostly aquatic snake (Halstead et al. 2014, 2019). To help manage species such as the giant garter snake, ecological baselines are established that underpin conservation and management expectations, planned interventions, and species management standards.

However, recent work in wildlife biology and applied zooarchaeology has increasingly highlighted how modern ecological baselines are inherently biased. These problems often stem from (1) unknown time depth and extent to which humans have modified the environment in the more ancient past, and (2) shifting baseline syndrome, where human perceptions regarding species populations change between generations and within individual lifetimes (e.g., Sáenz-Arroyo et al. 2005; Papworth et al. 2009; Turvey 2009; Wolverton and Lyman 2012; Malhi et al. 2016; Soga and Gaston 2018; Rodrigues et al. 2019). Given these concerns, multiple frameworks have been created to assess the extent to which humans impact populations today; however, many models still struggle to understand the degree to which humans impacted the environment prior to the European colonial period. This time-depth of anthropogenic influence is especially complicated in California, where the ethnographic and archaeological records highlight a rich history where humans actively manipulated the land and influenced species prevalence well before European colonization. Understanding these trends is particularly important for establishing ecological baselines for native Californian species (including food webs), because the ecology of California observed at European contact had been modified and managed by Native Californians for thousands of years.

This review explores the relationships between humans and wildlife in California prior to European contact through the lens of human niche construction, focusing on examples primarily from the San Francisco Bay, the Central Valley and Delta, and the surrounding foothills. We provide a general overview of California prior to European colonization alongside a discussion of theoretical frameworks used by California archaeologists that are relevant to wildlife biology. Drawing from archaeological studies, ethnographic research, and Traditional Ecological Knowledge (TEK), we then provide examples from Central 
California on how humans have impacted the spatial patterning of terrestrial species, flora and habitats, the life cycle of terrestrial targeted (e.g., actively hunted and gathered) and non-targeted species, fisheries, and human health and dietary patterns in the past. Finally, we conclude by discussing different ways these concepts might influence present-day fish and wildlife management, particularly the argument that one must consider human influences on species' ecological baselines and habitats. Collaborations between archaeologists and biologists are ongoing (e.g., Rick and Lockwood 2013; Scharf 2014), and this review provides insights into ways archaeology can further inform contemporary conservation management practices within California.

\section{Overview of the Central Valley and San Francisco Bay Area Archaeological Record}

Archaeological evidence suggests that the initial settlement of California occurred during the transition from the Late Pleistocene to Early Holocene, approximately 14,000 to 11,000 years ago (Erlandson et al. 2007; Meyer and Rosenthal 2008). During this time, sea levels were at an all-time low and much of the land that currently comprises the California coast would have been inland (Meyer and Rosenthal 2008; Lightfoot and Parrish 2009). Migration into California likely occurred through multiple routes into the interior and along the coast (Erlandson et al. 2007; Lightfoot and Parrish 2009). People from this time until roughly 8500-8000 calibrated (cal) B.C. hunted, fished, and gathered plant resources along coastal areas as well as inland areas with freshwater access (Lightfoot 1993; Erlandson 1994). Between roughly 9050 and 6050 cal B.C., sea levels rose by about 25 meters. Later, between 6050 cal B.C. and 4050 cal B.C., the San Francisco Bay estuary, tidal marshes, lagoons, flats, and protected bays and inlets were formed along the coast and in the California Delta (Rosenthal et al. 2007; Meyer and Rosenthal 2008).

While these large-scale changes in landscape were occurring, Native Californians were mobile and occupied small seasonal encampments instead of year-round villages (Meyer and Rosenthal 1997; Rosenthal and McGuire 2004). They had already adopted practices that would be observed in later historic and modern ethnographic accounts. For example, milling equipment for processing wild plant foods was used as early as $8500-8000$ cal B.C. in the San Francisco Bay Area and foothills of the Central Valley (Milliken et al. 2007; Meyer and Rosenthal 2008; Hildebrandt and McGuire 2019). There is also archaeological evidence that Native Californians harvested wild plant foods such as acorn, piñon, and wild cucumber (Meyer and Rosenthal 1997; Wohlgemuth 1997; Rosenthal and McGuire 2004). Evidence of stone tools sourced from far-away quarries throughout the Central Valley and Bay Area and the presence of California coast marine shells found in the Great Basin dating to 5500 cal B.C. reflect widespread trade networks across different regions of California (Bennyhoff and Hughes 1987; Meyer and Rosenthal 1997; Fitzgerald et al. 2005; Milliken et al. 2007; Rosenthal et al. 2007). By 4050 cal B.C., Central Valley groups were more sedentary, although seasonal high-mobility foraging was maintained in the foothills.

From 3500 cal B.C. to about 550 cal B.C. in the Valley and lowlands of the Bay Area, there were notable shifts towards sedentism, which included intensive use of local resource patches. Regional trade increased, mortars and pestles were adopted as more common tools alongside milling slabs, and people used ornamental items such as cut Olivella and Haliotis beads. Graves with high levels of ornamentation are found inside shell and earthen mound sites (Meyer and Rosenthal 1997; Milliken et al. 2007; Rosenthal et al. 2007). These constructed mounds, like the West Berkeley Mound (CA-ALA-307) and the Blossom Mound 
(CA-SJO-68), are among the oldest examples of shell and earthen mounds located in the San Francisco Bay Area and California Delta, respectively (Lightfoot and Luby 2002; Luby et al. 2006; Moratto 1984). Most important to discussions of wildlife management, faunal assemblages from these sites suggest Native Californians relied on a mosaic of resources from different habitats, especially the San Francisco Bay, freshwater and saltwater marshes, riparian forests, and grasslands (Broughton 1994a; Meyer and Rosenthal 1997; White 2003a,b).

Starting around $550 \mathrm{cal}$ B.C., there was a shift toward a cooler, wetter climate and less saline conditions in the Delta (Meyer and Rosenthal 2008). Many new specialized technologies became more common, and food economies shifted toward seasonal resources that could be bulk harvested, stored, and processed as staples, such as acorns (Basgall 1987; Wohlgemuth 1997, 2004; White 2003a,b). This trend became more notable through time until European contact. Furthermore, the presence of mound sites increased and expanded into the lower Sacramento Valley during this period, with a southern boundary of the lower foothill woodlands of the San Joaquin Valley (Schenck and Dawson 1929; Rosenthal et al. 2007). These mound sites contain remains of habitation structures such as hearths and house floors, extensive deposits of habitation debris, and burials, all of which suggest they may have served as large permanent and semi-permanent village centers that were occupied year-round or seasonally (White 2003a; Rosenthal et al. 2007). The distribution of mound sites was widespread, with ethnographers and archaeologists estimating that mounds were located approximately every two to three miles along the Sacramento River (Schenck and Dawson, 1929).

Native Californians experienced major periods of environmental change from A.D. 1000 until European contact. For example, this period includes the Medieval Climatic Anomaly (MCA), during which Native Californians experienced two punctuated periods of drought, higher average temperatures, and increased fire activity (Meko et al. 2001; Marlon et al. 2012; Meyer and Rosenthal 2008). Another severe drought occurred in the Sacramento watershed around approximately cal A.D. 1530 (Meko et al. 2001).

During this time period of environmental shifts, the density of archaeological sites increased and population estimates were some of the highest in Native North America (Cook 1976). Additionally, the bow and arrow were introduced, replacing the atlatl as the preferred hunting tool (Bettinger 2013). Fish weirs were constructed along rivers and streams near some of the larger mounds located in the northern Central Valley, where river corridors were narrower (Sundahl 1982; White 2003a). Villages and smaller camp sites were still common along river channels, sloughs, and other bodies of water (Schenck and Dawson 1929; White 2003a; Rosenthal et al. 2007). Harvesting of wild plants and fishing increased in importance, and archaeological evidence suggests that terrestrial species targeted for hunting were diverse and hunters increasingly focused efforts on smaller prey species (White 2003b; Wohlgemuth 2004).

By the late 1770s, California's Native population began to decline, likely caused in part by the introduction of infectious diseases by European settlers, which likely spread to Native Californians prior to the Mission Period (Preston 2002). Infectious Diseases such as syphilis and gonorrhea introduced to Native Californians continued to decimate populations through the Spanish Mission system (Jackson 1994; Preston 2002; Jackson and Castillo 2005). The Spanish Mission system subjected Native Californians to exploitative working conditions, poor quality diets, poor sanitation, and squalid living conditions at the missions throughout the California coast (Jackson 1994; Jackson and Castillo, 2005; Sandos 2008). Additionally, it functioned to erase social connections and the culture of Native Californians by convert- 
ing them to Christianity, breaking up family groups by sending people to missions far from home, and forcing labor, agricultural, and ranching practices on people so they could not as easily practice their own native foodways and culture (Jackson and Castillo 2005; Sandos 2008). Missionization also started the conversion of lands and the environment toward the landscape we see today by introducing non-native and invasive species, including European rodents and grasses alongside agricultural and livestock products such as cattle and wheat (Chartkoff and Chartkoff 1984; Anderson 2005). While the Mission system had a negative impact that continues to influence communities today, it is important to highlight that Native Californians mounted resistance in many ways, enabling them to maintain much of their culture and lifeways (Castillo 1978; Jackson and Castillo 2005; Akins and Bauer 2021).

When the United States assumed control of California and the Gold Rush began in 1850 , genocide and cultural erasure were accelerated and expanded to places in the interior where Spain and Mexico had not previously focused colonization efforts. Mining, lumbering, and agricultural practices as well as development of infrastructure like levees and urban construction led to modified waterways, marshes, meadows, forests, and grasslands (Starr 1980; Carle 2004; Anderson 2005; San Francisco Estuary Institute 2008). At the same time, Native Californians faced massacres, bounty hunting, enslavement, forced assimilation, and forced removal from ancestral homelands (Castillo 1978; Lindsay 2015; Madley 2017). In removing the Native Californians who managed their landscapes, the ecological patterns and discussion about what should be considered "normal" ecology changed through time. As a result of this history, both Native Californians and the native environment of California have been drastically transformed by Euro-American occupation.

\section{Niche Construction Theory and California Archaeology}

Since the 1980s, human behavioral ecology theory (HBE) has played a prominent role in California archaeology (Broughton 1999). Within HBE, optimal foraging theory (OFT) models predict a relationship between prey body size and energy gain, often framed using prey-rank or diet-breadth models (MacArthur and Pianka 1966; Schoener 1971; Charnov 1976). The diet-breadth model posits that human foragers will attempt to harvest the maximum net energy gained while hunting game with as little energy expended as possible. These models predict that human foragers in Late Holocene central California attempted to maximize energy gain relative to search costs during hunting forays and thus selected higher-ranked, large game resources over lower-ranked, smaller fauna regardless of their abundance on the landscape (Broughton 1999). When high-ranked prey items are significantly depleted within a local resource patch, foragers will select the next highest ranked prey item (i.e., diet-breadth expansion) or instead will focus efforts on more distant resource patches (MacArthur and Pianka 1966; Charnov 1976). Over time, declines in the relative abundance of high-ranking, larger prey relative to lower-ranked, smaller prey because of overhunting (i.e., resource depression) would signify a reduction in foraging efficiency (Bayham 1979; Broughton 1994a, b, 2002).

The diet-breadth model also predicts greater investment in lower-ranked plant resources and the technology used to process them as higher-ranked game resources are depleted from local resource patches (Basgall 1987; Wohlgemuth 1996). When tested in archaeological contexts, these approaches are framed as resource intensification models and used to predict temporal declines in the relative abundance of large game relative to lower-ranked resources (e.g., smaller game and wild plant resources), as tracked through archaeofaunal, archaeobo- 
tanical, and artifact assemblages (Basgall 1987; Broughton 1994a, b; Wohlgemuth 1996). In pre-European contact California, intensification models predict diet-breadth expansion marked by the increased investment in wild plant resources and lower-ranked fauna, reflecting a decrease in foraging efficiency (i.e., increased energy expenditure relative to caloric gain) and a decline in human skeletal and dental health (Broughton 1999; Bartelink 2006; Broughton et al. 2010; Bright and Bartelink 2013; Prince-Buitenhuys and Bartelink 2020).

In the Sacramento-San Joaquin Delta and San Francisco Bay Area, archaeologists have proposed that resource intensification played a role in the development of intensive acorn storage economies, greater use of small seeds, and greater investment in anthropogenic burning of the landscape (Broughton 1999, 2002). Evidence from numerous archaeological sites indicates that Native Californians increased their reliance on acorns and certain types of small seeds through time (Basgall 1987; Wohlgemuth 1996; Broughton 1999). In California, Late Holocene population growth is associated with increased sedentism, which in turn contributed to depression of local resource patches (Testart et al. 1982; Broughton 1999). Diet-breadth expansion continued into the late precontact period, although a postEuro-American contact rebound in large game populations has been documented in several archaeological contexts in the western US, likely resulting in part from a decline in the Indigenous population following European incursion into the area (Preston 1997, 2002; Butler 2000; Broughton 1999).

Niche construction theory (NCT) has recently been applied to further understand human-wildlife interactions in California history (Broughton et al. 2010; Prince-Buitenhuys and Bartelink 2020). Niche construction is an evolutionary process where organisms create or modify their own niche, which in turn may influence selective pressures for future descendants of that species and other species in the same ecosystem (Odling-Smee et al. 2003, 2013). This ecological inheritance can influence the effects or direction of natural selection. Archaeologists have recognized the compatibility of NCT and resource intensification models and their predictive power to explain how humans altered environments in Late Holocene California (Broughton et al. 2010; Riede 2019).

The pre-European contact record of Native Californian land use patterns demonstrates how environmental niches for native plant and animal species were anthropogenically altered and managed by Native Californians. Understanding the human-influenced pre-European "natural" landscape has major consequences for how we conceptualize baseline data (e.g., foodwebs) for managing species in modern environmental studies, including the kinds of environmental strategies that provide effective outcomes for plant and animal communities. Because the ecology of California observed at European contact was modified by Native Californians, the concepts about what constitutes the baseline of plant and wildlife populations are at least partially dependent on humans actively manipulating habitats. In other words, what is now considered "natural" as the baseline is different from the plant and animal communities managed by Native Californians.

\section{Examples of Human Niche Construction Impacts on Ecology}

Human influences on flora distribution.-Niche construction practices of Native Californians, especially within Central California, relied on the long-term management of resource patches such as oak trees, groves, or meadows, which influenced the presence of managed and unmanaged habitats across the landscape. The ethnographic record describes how many tribes held ownership rights based on resource management over specific lands 
and resources. This form of ownership provided families, individuals, and communities with exclusive rights to specific resources (Anderson 2005). Discrete patches owned by a group were marked by boundaries and could be inherited for generations through kinship and marriage. These managed areas were maintained through irrigating, weeding, burning, tilling, and pruning to maximize their abundance and productivity to meet cultural needs, including food resources and basket-making materials (Anderson 2005; Goode et al. 2018).

In archaeological contexts, these practices have been explored in relation to the use of anthropogenic burning for maintaining specific grassland habitats and maximizing harvests of key food resources. Plant foods such as acorns, piñon, berries, and roots, as well as wild game such as deer and elk, thrive within a managed fire regime based on archaeological evidence, ethnographic accounts, and modern ecology studies (Anderson et al. 1997; Anderson 2005; Keeley 2002; Lake 2013). Controlled burns aided in food resource productivity while also providing conditions conducive to the growth of plants used for cordage, baskets, nets, granaries, clothing, hunting and fishing implements, and weapons (Anderson 2005, pp. 136-137). In addition, fire was used to reduce the density of dead trees, grasses, and thick undergrowth to lower wildfire risk, create trails and corridors between resource zones and communities (Lake 2013), provide protection from outsiders and enemies (Keeley 2002), and aid in hunting (Anderson 2005).

The use of fire before European contact provides an example of how human niche construction helped maintain grassland and fire reliant flora to improve resource harvesting. For example, Keeley $(2002,2005)$ found that anthropogenic burning was instrumental in converting landscapes from shrubland to grassland along the North and South Coastal Ranges prior to European contact. In a study that examined fire regimes in the east San Francisco Bay Area during the $19^{\text {th }}$ century, Keeley (2005) found that natural fire regimes (e.g., fire from lightning strikes) cannot explain the long-term success of grasslands and further that shrubs would colonize grasslands without regular disturbance through humanstarted fires removing woody vegetation and/or heavy grazing and browsing. He goes on to argue that the population density in the East Bay (100 villages with over 2000 inhabitants) would have significantly impacted the size of herds of grazing and browsing species like deer and elk and that regular human-started fires would have been required to expand and sustain grasslands in the Bay Area (Keeley 2005).

The frequent use of anthropogenic burning is consistent with the findings from paleobotanical and phytolith studies at CA-SMA-113 in the Quiroste Valley, between ca. cal A.D. 1000-1300 (Cuthrell 2013). Charcoal analyzed from the site included very few firesusceptible trees and shrubs, such as Douglas fir (6.4\% of the charcoal assemblage), suggesting that those were not a common resource in the region. Instead, redwood, California lilac, and alder was significantly more prevalent in the charcoal assemblage (73.7\%). Redwood is extremely resistant to fire, and California lilac germinates in response to fire, suggesting their prevalence over fire-susceptible species such as Douglas fir and Coyote Brush was due, at least in part, to regular burning of the landscape (Cuthrell 2013). Most importantly, human-preferred resource bearing species that have harvests enhanced by fire were also prevalent. California hazel was the most common edible nut species identified $(85.5 \%$ by weight of the edible nut assemblage), and ethnographically is known to have been regularly burned by native peoples to produce more sprouts and nuts (Anderson 2005; Cuthrell 2013). Additionally, grass and forb seeds from species common to grasslands composed most of the seed assemblage (57.5\%), in line with expectations for a pre-European contact anthropogenically managed grassland landscape as predicted by Keeley $(2002,2005)$. 
The pattern of fire evidence over the past 3,000 years in California shows that fire prevalence and climate change were correlated before A.D. 1880, with evidence for increased fire activity during the Medieval Climatic Anomaly drought periods and a decline in fire during the wetter Little Ice Age (Marlon et al. 2012). While current data cannot be used to determine how much burning was from human activity versus lightning strikes before the 1800 s, both likely contributed to the ecology and managed resource patches present at European contact (Keeley 2002; Lake 2013; Lake et al. 2017).

During the late 1800s and early 1900s, the United States dramatically changed fire management in the West. While in the 1800s there was an increase in fires, fire suppression regimes such as that initiated by the US Forest Service in 1905 caused a build-up of fuels, a problem that continues to this day (Marlon et al. 2012). These new fire management practices ultimately led to long-term changes in wildfire patterns in the region. For example, the elimination of fire management activities such as the low-fuel, small-scale controlled fires used by Native Californians resulted in fundamental changes in the structure of forests, which historically included a mixture of tree density and size with a more open canopy structure, to a dense vegetative understory with a more closed canopy. These changes allowed for an overgrowth of plant species that thrive without fire like invasive weeds, decreased tree health which allowed the introduction of disease and pest species, and accumulation of fuel load that contributes to hotter fires that tend to kill fire-adaptive native tree species (Stephens et al. 2018). These changes in management strategies also resulted in the spread of juniper and sage into old-growth forests that invade habitats where high-heat wildfires have killed off trees and plants that would otherwise be maintained and even thrive with a regular low-heat fire regime (Anderson 2006).

In contrast to practices allowing increased spread of non-native species, recent studies have found that regular human-induced burns in areas where habitats, such as those in which vernal pools originally thrived, can help revive and rehabilitate native plant communities (Pollack and Kan 1998; Ditomaso et al. 2006; Cook and Hayes 2020). Similarly, using fire for clearing facilitates maintenance of different environmental patches (e.g., woodlands, meadows). The use of controlled burns is recognized as an effective management strategy for reducing the intensity of wildfires experienced recently in California (Anderson 2005, Lake 2013). Landscape management using small-scale prescribed burns could be worthy areas of collaboration between interested tribal parties, wildlife biologists, ecologists, and archaeologists to create better management practices for recovery of meadows and other habitats in regions they thrived in pre-European contact California.

It is worth noting, however, that local ecology, preferred resource patches and types, and even the impacts of climate through time all vary according to the region, and human niche construction had its limits. In the lower Sacramento Valley, for example, the resources exploited look very different than the patterns at CA-SMA-113 and other sites from the Bay Area and foothills. In the lower Sacramento Valley, represented by village sites CA-SAC-485 (550 cal B.C. - cal A.D. 150), and CA-SAC-15 (cal A.D. 580 - cal A.D. 1510), Themidaceae family geophyte corms were intensively used, a pattern distinct from dozens of other sites in the Bay Area and Central Valley outside of the lower Sacramento Valley (Wohlgemuth 2016). Furthermore, while both acorns and small seeds were intensified in the Sacramento Valley and the Bay Area, the pattern of intensification is slightly different; small seeds were found in extremely high densities at the two Sacramento County sites, with the increased prevalence (and predicted intensification) starting at least 2500 years ago (Wohlgemuth 
2004, 2010, 2016). CA-SAC-485 and CA-SAC-15 did not have as reliable of nut resources as other regions in the foothills and the Bay Area, as Valley Oaks were the only source of edible nuts and those rank low as resources compared to black or blue oak (Wohlgemuth 2016). Given this, context-specific research into past trends are important to understand how the mosaic of habitat patches functioned pre-European contact and the nature of resources targeted by human communities. This information will likely impact which species directly and indirectly benefited, and which were suppressed, in any given region.

Terrestrial fauna, buffer zones, and edge habitats. - Gathering areas were specialized niches similar to tended gardens that patterned the landscape with wilds, trails, and waterways in between them. These practices helped maintain a complex patchwork of microenvironments that influenced the variety of game and plant resources available within a daily foraging radius of a village site (Broughton 1994a, 1994b; Lightfoot \& Parrish 2009; Broughton et al. 2010). However, these practices could also result in localized resource depression of some game species within these managed areas, depending on strategies employed and local population density.

The establishment and maintenance of patches would have created a series of anthropogenic edge habitats likely used by many target and non-target wildlife species in pre-European California. The use of anthropogenic and naturally-occurring edges has been demonstrated in various species ranging from large carnivores such as grizzly bear (Ursus arctos horribilis) (Stewart et al. 2013), which is now extirpated from its former range in California, down to small invertebrates such as ground beetles (Magura and Lovei 2020). Depending on the techniques used to maintain these edges, dispersal and use of the habitat could potentially vary from that of naturally occurring edges and result in modified species assemblages in the anthropogenic edge as compared to the naturally occurring edge. Linear anthropogenic edges could also have supported a higher diversity of plant species (Suarez-Esteban et al. 2016) and provided additional desirable plants beyond those maintained within the patches. In modern times, this edge-related plant diversity and abundance can potentially favor non-native or exotic species (i.e., plant species that were not present at the time of European contact).

These resource patches with inherited rights and established seasonal or annual camps and villages meant that territory was extremely important and relevant in Native California, even though it was not conceptualized in the same way as Euro-American ownership. People maintained their own gardens, fishing spots, and hunting grounds so they could maximize the range of available resources, especially as higher-ranked, larger fauna were depleted locally. Some archaeologists have theorized that because of the mosaic of maintained patches and variety of resource access, Native Californians were able to maintain higher population density circa-A.D. 1000, mitigating the effects of resource depression (Broughton et al. 2010). These patterns are predicted to have led to increased defense of territories and the creation and maintenance of buffer zones, which are defined as areas between territories that may have been used as hunting grounds but that also served as areas where adjacent groups could minimize interaction and, therefore, prevent conflict (Bayham et al. 2012, 2019).

Areas located between these gathering patches would effectively become buffer zones with reduced hunting pressure on species that would have been targeted within the gathering areas. These zones would function as refuges for those species, allowing for increased survival of individuals compared to those that remained within the gathering areas. Behavioral avoidance of gathering patches during times of high hunting pressure would reinforce the 
function of these spaces. This behavioral avoidance of areas with high hunting pressure is seen today in a wide variety of species such as northern pintail (Casazza et al. 2012) and red deer (Lone et al. 2015). For example, studies have shown shifts in distance traveled and exploratory behavior in white-tailed deer (Odocoileus virginianus; Marantz et al. 2016) and an increase in distance from roadways, use of cover, and vigilance behavior of elk (Cervus elaphus; Paton et al. 2017, Cleveland et al. 2012) during times of increased hunting pressure. These behaviors allow the species to better avoid predation and unwanted encounters with, for example, vehicle traffic.

These patterns of buffer zones and managed spaces likely had significant consequences for the outcomes of populations of species prehistorically. For example, the Tule elk from the Emeryville area likely underwent a population bottleneck starting around approximately cal A.D. 350 based on ancient DNA studies from the Emeryville Shellmound (CA-ALA-329) (Broughton et al. 2013). OFT models previously predicted that Tule elk underwent resource depression due to changes in the relative abundance of elk compared to other, lower ranked prey species, and this predicted pattern is reflected in the "Elk Index" across sites along the San Francisco Bay shoreline (Broughton 1994b, 1999; Broughton et al. 2013). The lack of variation in carbon, nitrogen, and oxygen isotopic values through time for the Tule elk from Emeryville further suggests that climate change is unlikely to be the cause of this variation (Broughton et al. 2013). Given this, it seems likely humans hunted Tule elk so intensely that it resulted in a population bottleneck, but the population was able to survive despite intensive hunting pressure. This is in contrast to sea otters found in faunal assemblages around Bay Area sites after cal A.D. 1 (Broughton 1994a; Milliken et al. 2007), which were hunted heavily pre-European contact but did not experience a genetic bottleneck event even during heavy fur trades of the $18^{\text {th }}$ through early $20^{\text {th }}$ century (Larson et al. 2012).

Similar to patterns observed for wild plant collection and use, however, it is once again important to remember these generally described patterns of systems are specific to species and location. A study of the relative abundance of artiodactyl remains at the Emeryville Shellmound compared to other common lower ranked fauna in the collection (for the Bay Area - sea otters) has found that artiodactyl remains are less common through time in the region (Broughton et al. 1994b). In comparison, the Sacramento Valley data show minimal resource depression of artiodactyls when comparing their remains to small fish and also to lagomorphs and rodent species, but the trend in the Sacramento Valley examines freshwater and anadromous fishing compared to hunting and trapping of terrestrial mammals (Broughton 1994a; Broughton et al. 2010). These patterns do not translate across studies however, even using the same indices. Other studies examining the general trends of artiodactyl indices throughout Central California have suggested that deer, elk, and pronghorn in the rest of California were not over hunted and even underwent population increase through the Holocene (Codding et al. 2010; Whitaker et al. 2019). Examination of sites throughout the Bay Area have also found evidence that the trends for artiodactyl hunting observed archaeologically tend to vary between microhabitats (Milliken et al. 2007).

Given this variability of species hunting and prevalence across locations and time, it is extremely challenging to estimate baseline data for a species population such as Tule elk or other artiodactyls. Human influences are likely strongly tied to past population bottlenecks and the patterning of buffer zones and habitat patches across the state, especially in areas that exhibited high population density before European contact. California archaeologists are regularly expanding zooarchaeological data sets through Cultural Resources Management studies, and faunal collections are housed in museums and curation facilities across 
the state that have not been exhaustively studied. This means there is potential for many forms of studies with many available data sources. However, much of this zooarchaeological data are in confidential reports that can be difficult to access, and even when accessed not all reports use the same collection/sampling strategies or analytical methods. Given this, collaboration with archaeologists is key to conducting applied zooarchaeological studies for conservation management purposes.

Fishing patterns before European contact.-Another important case study is understanding precontact fishing patterns in California, especially the use of salmon as a key source of protein. Isotopic, zooarchaeological, and ethnographic data provide a rich and important record of this practice (Broughton 1988, 1994a; Yoshiyama et al. 1998, 2001). Salmon bones are rare in archaeological sites from the Delta and mid-Central Valley, but they are more abundant in foothill sites adjacent to the Valley where the creeks and rivers become narrower and shallower and in the upper reaches of the Sacramento River in the northern Sacramento Valley (Broughton 1988, 1994a). The increase in the relative abundance of salmon relative to smaller resident fishes with latitude does not appear to be a taphonomic issue and is corroborated by an abundance of salmonid bone and stable carbon and nitrogen isotope evidence on human skeletons at the Abbott Site (CA-SHA-1043), located along a narrow section of the Sacramento River (Hildebrandt and Darcangelo 2007; Bartelink et al. 2017). Like marine and estuarine fish, salmon feed from marine resources and carry a high trophic-level marine isotopic signature into freshwater streams and rivers of the Central Valley when they migrate and spawn. At the Abbott site, carbon and nitrogen isotope data from human bone collagen reveals that, on average, $29 \%$ of the dietary protein consumed by people derived from salmon, compared to several archaeological sites in the mid-Central Valley and Delta region, where salmon likely contributed only about $13 \%$ of the dietary protein consumed (Bartelink et al. 2017). The isotopic signature of individuals at SHA-1043 more closely resemble coastal people, whereas individuals from sites along the Sacramento River and its tributaries near modern-day Sacramento and Stockton consumed freshwater fish and terrestrial mammals as their main protein source.

The zooarchaeological record of SHA-1043 supports these results. The faunal record is nearly evenly split between mammals representing $48 \%$ and fish representing $49 \%$ of the total assemblage. Combined, salmon and steelhead represent over half of the total fish assemblage, and Sacramento suckers and minnows like Sacramento pikeminnow and hardhead represent 29\% and 26\% respectively (Garibaldi and Hildebrandt 2007; Hildebrandt and Darcangelo 2008). This evidence suggests salmon were not mass-captured (and therefore were underutilized) in much of the mid-Central Valley and Delta until they got far enough upstream to spawn.

It appears that smaller bodied freshwater fishes were targeted instead of salmon in the lower Sacramento Valley and Delta during the past 1,000 years (Schulz and Simmons 1973; Schulz 1979; White 2003a; Miszaniec et al. 2018). Fishes, including Sacramento perch, hitch, splittail, Sacramento blackfish, tule perch, and thicktail chub, are most common in slow water habitats like oxbows, pools, and marshes which are common in the region (Schulz and Simmons 1973; Moyle 2002). The fish assemblage at two sites in Contra Costa County, CA-CCO-138 and CA-CCO-139, was dominated by cyprinid remains $(\mathrm{n}=688)$, however only 26 individual specimens were identifiable to species (Miszaniec et al. 2018). Of the remaining fish assemblage identified to species, Sacramento perch dominated with 338 individual identified specimens, followed by 33 sturgeon elements (Miszaniec et al. 2018). Additionally, 51\% of the total identified fish at the Stone Lake site in Sacramento 
County were Sacramento perch, with $86 \%$ of the total fish identified being slow water species (Schulz and Simmons 1973). Nearly 98\% of the fishes recovered at CA-COL-1, the Patwin village Tsaki which was occupied into the Historic era, were slow water species (Schulz 1979). At this site, Sacramento perch accounted for nearly $25 \%$ of the total; however, thicktail chub, which were considered extinct as of 1957, dominated the assemblage at 41\% (Schulz 1979; Moyle 2002). Just north of CA-COL-1, several sites along Highway 45 not only exhibit increased use of fish through time especially after A.D. 770, but they also demonstrate increased use of slow water fishes (White 2003a; Rosenthal et al. 2007). While Sacramento perch was abundant in the slow-water fish assemblage at these sites, sturgeon and salmon species were also recovered in large quantities (White 2003a). Combined, the trends of fish use at archaeological sites in the Central Valley reflect the general animal and plant exploitation trends of the past 1,000 years. These examples highlight how there is not a one-size-fits-all pattern or strategy that can be used to describe all of California.

Evidence of fishing technology can also be used to infer general patterns of fishing activity before European colonization. However, fish harvesting technology is largely constructed with soft materials like textiles and wood, which are usually not recovered in archaeological contexts (Rosenthal et al. 2007). The primary evidence of fishing technology is stone net weights and sinkers, hafted biface knives for descaling and cutting, and occasionally bone harpoon points, gorges, and hooks (Bennyhoff 1950; Kroeber and Barrett 1960; Hester and Follett 1975). Facilities constructed to aid in harvesting such as dams, weirs, traps, and fishing platforms are constructed in stream channels and are off-site fixtures that, if they survived, may be overlooked during archaeological investigations (Rosenthal et al. 2007). These facilities were temporary in nature and therefore did not permanently block fish from their upstream spawning grounds (Kroeber 1925; Heizer 1978; Anderson 2005; Goode et al. 2018). The increase in plant and fish harvesting and the soft technologies used for procuring and processing both may in part explain the reduction in stone tools recovered from village sites that date after A. D. 770 (Rosenthal et al. 2007).

Impacts of niche construction and resource depression on human diet and health.-In addition to impacts on wildlife, human niche construction can impact human health and diet. Archaeological studies of ancient human health and paleodiet often rely on the biocultural approach (e.g., Zuckerman and Martin 2016; Cheverko et al. 2020), which recognizes that human environments consist of ecological, physical, and cultural components that include social groups, large communities, and every-day influences on human lives such as social norms, rules, guidelines, interpersonal relationships, and community behaviors (PrinceBuitenhuys and Bartelink 2020). As such, culture can act as a buffer to lessen impacts of external stressors, but it can also induce stressors that might not otherwise exist in a given ecological setting (Prince-Buitenhuys and Bartelink 2020). Importantly, this biocultural approach and NCT framework can be used to generate testable hypotheses, such as whether the prevalence of skeletal indicators of health increase or decrease in a specific environment. When applied to precontact Central California, NCT can be used to predict that resource depression and the development of acorn storage economies resulted in an overall reduction in dietary quality that negatively impacted human health, marked by increases in the prevalence of non-specific indicators of stress (e.g., stature reduction, periosteal bone lesions, enamel hypoplasia, scars of anemic response, etc.) and changes in diet through time (Bartelink 2006; Broughton et al. 2010; Prince-Buitenhuys and Bartelink 2020). For the Sacramento-San Joaquin Valley in particular, Late Holocene trends suggest a decline in skeletal health, marked by a temporal decline in stature and an increase in enamel hypoplasia 
defects, periosteal bone lesions, and scars of anemia (i.e., cribra orbitalia; Bartelink 2006; Broughton et al. 2010).

There is ample information about past human health and paleodiet based on the Marsh Creek (CA-CCO-548) site, located in present-day Contra Costa County in a transitional zone between the San Francisco Bay and California Delta (Wiberg 2010; Bartelink et al. 2020). Stable isotope analysis of human burials from this site suggests a dietary emphasis between the diets of individuals consuming freshwater and terrestrial resources in the Delta and individuals consuming more marine resources in the San Francisco Bay Area (Bartelink et al. 2020). While the relative protein source remained stable through time at Marsh Creek, there was an increased reliance on wild $\mathrm{C}_{3}$ plant resources through time, consistent with resource intensification models (Bartelink et al. 2020). In addition to dietary data, studies of human health (using physiological stress indicators as a proxy) from Marsh Creek demonstrate that individuals experienced high rates of dental attrition and low rates of dental caries (Griffin 2014), especially compared to other contemporaneous sites (Kolpan and Bartelink 2019). These differences in oral health indicators might be explained by dietary composition, cultural behaviors such as using teeth as tools, and the influence of certain plants on the oral biofilm that inhibit the development of dental caries (Griffin 2014), highlighting how the combination of cultural and environmental factors influenced human health in the past. Taken together, the paleodiet and dental health information support assertions that locally constructed niches impacted the food resources utilized within that environment, which contributed to patterns of human health.

The Canyon Oaks site (CA-ALA-613/H) provides a second case study in which one can interpret the effects of environmental change using an NCT lens, because the site was continuously occupied for a period of about 3600 years, including before, during, and after a period of extreme drought during the MCA (Pilloud 2006). The temporal span of this site allowed for a diachronic study of human remains to understand whether markers of skeletal stress and disease increased during the period of environmental instability as would be predicted during times of environmental stress. The prevalence of dental caries declined in males through time, but significantly increased in females during the MCA before declining again afterward. Another stress indicator, linear enamel hypoplasias (LEH), form on teeth during enamel formation and occur as linear bands of deficient enamel caused by physiological stress (e.g., malnutrition, infectious disease). While the prevalence of LEH may have increased during the drought period, there were no significant diachronic changes in LEH overall or in stature or interpersonal violence between the three periods (Pilloud 2006), providing variable evidence for drought-related effects on human health. Pilloud (2006) concludes that individuals living at this site developed new cultural practices such as new subsistence strategies to help them mitigate the environmental pressures they faced, and that some of these strategies may have varied by sex. This study concluded that culture may have buffered individuals against physiological stressors associated with adverse environments. In comparing the patterns observed at this site compared to contemporaneous sites, it is clear that drought did not affect all individuals and populations the same way (Pilloud 2006; Jones and Schwitalla 2008; Schwitalla and Jones 2012).

These two case studies demonstrate how bioarchaeological research uses inferences from human skeletal remains to provide insights into past human-environment interactions and the symbiotic effect of the environment and culture on ancient health. As demonstrated by health patterns from these archaeological sites and others, complementary lines of evidence from the San Francisco Bay Area and California Delta present variable histories 
of diet and health that are intrinsically linked to the local environment; thus some patterns cannot be generalized across regions or time periods. Variation in cultural and physical environments steered local health and dietary patterns in Central California, both within and between environments, with human constructed niches impacting these patterns on local levels. Concurrently, interactions between Native Californians and their environments led to further alterations of these niches, especially on local levels.

\section{Lessons for Contemporary Species Management}

California's ecological norm has been a managed landscape in both the past and present. The natural resources and wildlife of California have been managed by humans for at least the past 13,000 years. For thousands of years, Native Californians have manipulated their environment and constructed niches as a form of biocultural adaptation, and these niches have influenced the evolution and adaptations of future generations. Given the time depth of California's archaeological record, the dynamics between humans and other species, flora and fauna alike, have been complex. While they have led to periods of stress on some populations of species such as artiodactyls, they have helped others such as trees and brush that thrive in low-heat fire. People living in different regions were affected by environmental changes, resource availability, and population growth in a myriad of ways, none of which are easily generalized across Central California. What follows are three important lessons and considerations for contemporary wildlife management.

\section{There has been no "natural" California without human presence for millennia.}

It is important to remember that one of the fundamental assumptions that came with European colonization was the belief that the land was somehow "untamed", "pure", or "wild". In other words, they assumed it was free from significant human influence. However, Native Californians successfully managed their landscapes in ways that provided benefits for them and their target flora and fauna species, leading to altered landscapes shaped by the people who lived there.

Nevertheless, several new management practices were enacted following European contact that were based on the assumption of an untamed landscape, including movements for fire suppression starting in 1905, environmentalist movements starting with naturalists like John Muir, and attempts to end logging altogether in the 1970s. These practices combined to form long-term impacts on the environment. Similar policy decisions and misunderstandings at times by the scientific community about the relationship of California's naturally human landscape have led to decreased abundance of once common species, reduction in habitats of species that thrive with regular low-heat burn regimens, and an increased prevalence of non-native species and species that thrive without managed landscapes that would otherwise suppress them, such as poison oak and thistle, or in some areas of the Bay shrubland and Douglas Firs.

Given these factors, estimations of ecological baselines and assumptions about population histories for species in California should take into consideration the roll humans have played prehistorically in manipulating the environment and influencing the species in question. If models underpinning management plans, population prevalence, and more start from some base assumptions that human influence is a natural part of the species history, that would be a benefit. However, an even bigger benefit may be incorporating data from the archaeological record regarding the species in question, and conducting studies on 
archaeological resources to better understand the relationship of the species with humans, animal migration routes, species genetic diversity in deep time, and even the kinds of human induced or human related pressures the species has experienced before in different contexts.

\section{Human cultural patterns have a large impact on local environments.}

Even prehistorically, human management decisions, such as what resources to target and which resources were valuable had important roles in changing the outcomes of species. Tule elk underwent a population bottleneck in the Bay Area potentially due to overhunting. Meanwhile, sea otters were unaffected despite their heavy exploitation, yet artiodactyl populations were reduced at the Emeryville Shellmound, while other artiodactyl species in other regions did not experience the same level of hunting pressure. Some strategies even served the interest of species; salmon fishing occurring primarily in the foothills and the use of temporary dams and weirs helped the fish have access to spawning grounds and opportunities despite human predation, for example. Given the wide-ranging consequences of humans on habitats and other species, it makes sense to consider even more critically the kinds of roles humans had for specific species in different environments and regions throughout California when trying to establish an ecological baseline for management purposes.

Another important point is that the use of strategies (e.g., maintained patches, buffer zones, anthropogenic burning, and weir use) for landscape management also involve multiple specific cultural and behavioral attitudes and habits that sustain them. Burning as a practice is an excellent example because tribal groups and families who tended their own areas were responsible for burning their local landscapes prior to European colonization, as opposed to the large organizations and agencies responsible for organizing prescribed burns in contemporary management practices. This concept of localized land management responsibility is slowly being re-implemented in California today through a variety of programs that build collaborations between tribal partners and state, local, and federal entities (Lake et al. 2017; Goode et al. 2018). If people are trained to conduct small-scale controlled burns in an environmentally responsible fashion, they will be able to decrease fuel loads, reduce risks of catastrophic wildfires, improve the health of ecosystems in which native species thrive, and provide better outcomes for society. This initiative requires a societal change toward the use of anthropogenic burning, with improved collaboration, communication, and coordination between tribes, agencies, government, and local landowners (Lake et al. 2017; Rougle 2019). It also requires the creation and maintenance of easily accessible training opportunities for people to learn how to conduct safe prescribed burns. In turn, other downstream benefits include the development and maintenance of vegetation overgrowth, the creation of better soil for crops and some native species of interest, and the reduced risk of homes being destroyed during mega-fires. In addition, governments at all levels could work alongside community organizations to provide financial incentives for developing programs aimed at furthering research, learning opportunities, and chances to implement land management strategies (Lake et al. 2017; Rougle 2019).

3. Human involvement in environmental management can impact human outcomes.

Archaeological evidence supports the argument that Native Californians were able to influence their own health by adopting new technology and developing other cultural practices that helped them further establish their niches within localized environments. This resilience is not new, did not always involve idyllic outcomes for people or wildlife, and did not result in universal patterns between micro-environments or regions. Similar to the floral 
and faunal data from pre-European contact California, variable outcomes and patterns of health have been observed at different archaeological sites in Central California. However, this basic concept that people can adapt to their environment while simultaneously altering their environment continues into the modern day and is part of California's natural history.

Some of the practices that were used for managing species recorded in the ethnographic record were present and used before European contact, based on the archaeological record. These practices and the suite of knowledge they are based on, referred to as Traditional Ecological Knowledge (TEK) and traditional land management practices, are becoming more widely recognized as effective tools for counteracting climate change within California (Goode et al. 2018). TEK and traditional land management may serve as great resources to help reconceptualize ecological baselines and the kinds of management strategies effective to help achieve these goals.

There are many historical and community factors that impact the use of TEK today in California. After the initial impacts of the Spanish Mission system, the policies, acts, and decisions by the Bureau of Indian Affairs, the State of California, and the US government continued to systematically impact Native Communities, leading to the high rates of poverty, food insecurity, and poor health conditions, especially related to diet-related diseases, which are issues that continue today (Castillo 1978; Sowerwine et al. 2019a). Many tribal communities have been mounting efforts to reclaim their past, traditional knowledge of native ecology, and culture. Many tribal groups are also working to revitalize their communities through education, outreach, food sovereignty movements, and attempts to reclaim rights to traditional and sacred lands (Milliken et al. 2009; Sowerwine et al. 2019a,b; Wires and LaRose 2019). TEK is intrinsically tied to the health and welfare of California tribal communities and their history. What TEK is known and remembered is not the exact same as it was at European contact. Similarly, it likely changed even between the multiple generations over the thousands of years people have occupied California; Native Californian land management practices and culture changed since humans entered the state based on the archaeological record, and TEK by necessity has likely transformed over time with it. Despite this, much TEK has survived and is still used and practiced to this day.

Traditional land management using TEK has been shown to be a potentially effective tool in conservation efforts and against commonly experienced health problems in Native Communities, including depression, addiction, and diet-related diseases such as diabetes (Goode et al. 2018; Sowerwine et al. 2019a). For example, studies have shown that the prevalence of diabetes in tribal communities is inversely related to access to traditional food resources, meaning that communities that reclaim their traditional dietary practices tend to have lower incidence of diabetes and other metabolic conditions (Sowerwine et al. 2019a). The outcomes of a five-year grant to help the tribes of the Klamath River Basin move toward food sovereignty provide a clear example of these potential impacts but is beyond the scope of this review (for more information, see Sowerwine et al. 2019a). However, an additional potential benefit to such collaborations and initiatives beyond direct impacts to the Native Californian community is the promotion of native species traditionally harvested for food. Initiatives such as these also represent the potential for further multi-agency collaborations between tribal, local, state, and federal organizations that can benefit the environment, community, health outcomes, and equity initiatives for marginalized groups.

Concluding thoughts.-Humans have always had a complex relationship with the environment, where culture can act as either a buffer or catalyst to environmental stressors. 
Humans create niches in all environments in which they live, managing the landscape in ways that are often mutually beneficial for humans and wildlife. Thus, biologists are faced with a challenge when it comes to accounting for the thousands of years of accumulated impacts of humans interacting with their environment on species populations, especially for estimating ecological baselines. Archaeological data can help address this dearth of information in California by providing insights into the effects of human niche construction prior to European contact. Furthermore, by understanding the archaeological record, it may be easier to also understand how different human land use strategies impacted habitats and species, and how those relationships changed through time.

\section{LITERATURE CITED}

Akins, D. B., and W. J. Bauer. 2021. We Are the Land: A History of Native California. University of California Press, Oakland, CA, USA.

Anderson, M. K. 2006. The use of fire by Native Americans in California. Pages 381-397 in N. G. Sugihara, editor. Fire in California's Ecosystems. University of California Press, Oakland, CA, USA.

Anderson, M. K. 2005. Tending the Wild: Native American Knowledge and the Management of California's Natural Resources. University of California Press, Berkeley, CA, USA.

Anderson, M. K., M. G. Barbour, and V. Whitworth. 1997. A world of balance and plenty: land, plants, animals, and humans in a pre-European California. California History $76(2-3): 12-47$.

Bartelink, E. J. 2006. Resource intensification in pre-contact central California: a bioarchaeological perspective on diet and health patterns among hunter-gatherers from the lower Sacramento Valley and San Francisco Bay. Dissertation, Texas A\&M University, College Station, TX, USA.

Bartelink, E. J., J. Nelson, J. Furlong, S. Kline, J. Prince-Buitenhuys, A. MacKinnon, and F. Bayham. 2017. Stable isotope evidence for the consumption of salmon in the prehistoric Sacramento Valley of California. Paper presented at the annual meetings of the American Association of Physical Anthropologists, New Orleans, LA, USA.

Bartelink, E. J., M. M. Beasley, J. W. Eerkens, K. S. Gardner, R. S. Wiberg, and R. Garibay. 2020. Stable isotope evidence of diet breadth expansion and regional dietary variation among Middle-to-Late Holocene hunter-gatherers of central California. Journal of Archaeological Science: Reports 29:102182.

Basgall, M. E. 1987. Resource intensification among hunter-gatherers: acorn economies in prehistoric California. Pages 21-52 in I. L. Barry, editor. Research in Economic Anthropology, Volume 9. JAI Press, Emerald Publishing, Bingley, UK.

Bayham, F. E. 1979. Factors influencing the archaic pattern of animal exploitation. Kiva 44(2-3):219-235.

Bayham, F. E., R. K. Beck, and K. L. Carpenter. 2012. Large game exploitation and intertribal boundaries on the fringe of the western Great Basin. Pages 103-123 in D. Rhode, editor. Meetings at the Margins: Prehistoric Cultural Interactions in the Intermountain West. University of Utah Press, Salt Lake City, UT, USA.

Bayham, J., K. E. Cole, and F. E. Bayham. 2019. Social boundaries, resource depression, and conflict: A bioeconomic model of the intertribal buffer zone. Quaternary In- 
ternational 518:69-82.

Bennyhoff, J. A., and R. E. Hughes. 1987. Shell bead and ornament exchange networks between California and the Great Basin. Anthropological Papers of the American Museum of Natural History 64:79-175.

Bennyhoff, J. A. 1950. Californian Fish Spears and Harpoons. Anthropological Records 9(4):295-338.

Bettinger, R. L. 2013. Effects of the bow on social organization in Western North America. Evolutionary Anthropology 22(3):118-123.

Bright, L., and E. J. Bartelink. 2013. Health and nutritional status at CA-SOL-451 (Encinosa Site): biological interpretations and regional comparisons. Pacific Coast Archaeological Society Quarterly 49(1):85-104.

Broughton, J. M. 1988. Archaeological patterns of prehistoric fish exploitation in the Sacramento Valley. Thesis, California State University, Chico, CA, USA.

Broughton, J. M. 1994a. Late Holocene resource intensification in the Sacramento Valley, California: the vertebrate evidence. Journal of Archaeological Science 21(4):501514.

Broughton, J. M. 1994b. Declines in mammalian foraging efficiency during the Late Holocene, San Francisco Bay, California. Journal of Anthropological Archaeology 13(4):371-401.

Broughton, J. M. 1999. Resource depression and intensification during the late Holocene, San Francisco Bay: Evidence from the Emeryville Shellmound vertebrate fauna. Dissertation, University of California, Davis, CA, USA.

Broughton, J. M. 2002. Prey spatial structure and behavior affect archaeological tests of optimal foraging models: examples from the Emeryville Shellmound vertebrate fauna. World Archaeology 34:60-83.

Broughton, J. M., M. D. Cannon, and E. J. Bartelink. 2010. Evolutionary ecology, resource depression, and niche construction theory: applications to central California hunter-gatherers and Mimbres-Mogollon agriculturalists. Journal of Archaeological Methods and Theory 17:371-421.

Broughton, J. M., R. K. Beck, J. B. Coltrain, D. H. O’Rourke, and A. R. Rogers. 2013. A late Holocene population bottleneck in California tule elk (Cervus elaphus nannodes): Provisional support from ancient DNA. Journal of Archaeological Method and Theory 20:495-524.

Butler, V. L. 2000. Resource depression on the northwest coast of North America. Antiquity 74(285):649-661.

Carle, D. 2004. Introduction to Water in California. University of California Press, Berkeley, CA, USA.

Casazza, M. L., P.S. Coates, M. R. Miller, C. T. Overton, D. R. and Yparraguirre. 2012. Hunting influences the diet patterns in habitat selection by northern pintails Anas acuta. Wildlife Biology 18(1)1-13.

Castillo, E. D. 1978. The impact of Euro-American exploration and settlement. Pages 99-127 in R. F. Heizer, editor. California, Handbook of North American Indians, Volume 8. Smithsonian Institution, Washington D.C., USA.

Charnov, E. L. 1976. Optimal foraging, the marginal value theorem. Theoretical Population Biology 9(2):129-136.

Chartkoff, J. L., and K. K. Chartkoff. 1984. The Archaeology of California. Stanford Uni- 
versity Press, Stanford, CA, USA

Cheverko, C. M., J. R. Prince-Buitenhuys, and M. Hubbe. 2020. Theory in bioarchaeology: an introduction. Pages 1-14 in C. M. Cheverko, J. R. Prince-Buitenhuys, and M. Hubbe, editors. Theoretical Approaches in Bioarchaeology. Routledge, Abingdon, VA, USA.

Cleveland, S. M., M. Hebblewhite, M. Thompson, and R. Henderson. 2012. Linking elk movement and resource selection to hunting pressure in a heterogeneous landscape Wildlife Society Bulletin 36:658-668.

Codding, B. F., J. F. Porcasi, and T. L. Jones. 2010. Explaining prehistoric variation in the abundance of large prey: a zooarchaeological analysis of deer and rabbit hunting along the Pecho Coast of Central California. Journal of Anthropological Archaeology 29(1):47-61.

Cook, D., and M. Hayes. 2020. Post-fire species composition and abundance of a lenticbreeding amphibian assemblage: case study of Ledson Marsh. California Fish and Wildlife Journal, Fire Special Issue, 110-128.

Cook, S. F. 1976. The Population of the California Indians, 1769-1970. University of California Press, Oakland, CA, USA.

Cuthrell, R. Q. 2013. Archaeobotanical evidence for Indigenous burning practices and foodways at CA-SMA-113. California Archaeology 5(2):265-290.

Ditomaso, J. M., M. L. Brooks, E. B. Allen, R. Minnich, P. M. Rice, and G. B. Kyser. 2006. Control of invasive weeds with prescribed burning. Weed Technology 20(2):535548.

Erlandson, J. 1994. Early Hunter-Gatherers of the California Coast. Interdisciplinary Contributions to Archaeology. Springer, Boston, MA, USA.

Erlandson, J. M., T. C. Rick, T. L. Jones, and J. F. Porcasi. 2007. One if by land, two if by sea: who were the first Californians? Pages 53-62 in T. L. Jones and K. A. Klar, editors. California Prehistory Colonization, Culture, and Complexity. AltaMira Press, Lanham, MD, USA.

Fitzgerald, R. T., T. L. Jones, and A. Schroth. 2005. Ancient long-distance trade in Western North America: new AMS radiocarbon dates from Southern California. Journal of Archaeological Science 32(3):423-434.

Garibaldi, J., and W. Hildebrandt. 2007. Data Compendium for Life on the River: History of the Wintu People as seen from Archaeological Site CA-SHA-1043, Kum Bay Xerel (shady Oak Village). Journal of California and Great Basin Anthropology 28(1):109-111.

Goode, R., S. Gaughen, M. Fierro, D. Hankins, K. Johnson-Reyes, B. R. Middleton, T. Red Owl, and R. Yonemura. 2018. Summary Report from Tribal and Indigenous Communities within California. SUM-CCCA4-2018-010, California's Fourth Climate Change Assessment.

Griffin, M. C. 2014. Biocultural implications of oral pathology in an ancient central California population. American Journal of Physical Anthropology 154:171-188.

Halstead, B, J. Rose, G. Reyes, G. Wylie, and M. Casazza. 2019. Conservation reliance of a threatened snake on rice agriculture. Global Ecology and Conservation 19:1-11.

Halstead, B., G. Wylie, and M. Casazza. 2014. Ghost of habitat past: historic habitat affects the contemporary distribution of giant garter snakes in a modified landscape. Animal Conservation 17:144-153. 
Heizer, R. F. 1978. California. Handbook of North American Indians Volume 8. Smithsonian Institution, Washington D.C., USA.

Hester, T. R., and W. I. Follett. 1975. Yurok fish knives: a study of wear patterns on adhering salmon scales. Contributions of the University of California Archaeological Research Facility 33(1):1-23.

Hildebrandt, W. R., and K. R. McGuire. 2019. 7,000 Years of Native American History in the Sacramento Valley: Results of Data Recovery Excavations near Hamilton City, California. U.S. Army Corp of Engineers.

Hildebrandt, W. R., and M. J. Darcangelo. 2008. Life on the river: the archaeology of an ancient Native American culture. Janus Publishing Company Ltd, Cambridge, UK.

Jackson, R. H. 1994. Indian Population Decline: The Missions of Northwestern New Spain, 1687-1840. University of New Mexico Press, Albuquerque, NM, USA.

Jackson, R. H., and E. D. Castillo. 2005. Indians, Franciscans, and Spanish colonization: The Impact of the Mission System on California Indians. University of New Mexico Press, Albuquerque, NM, USA.

Jones, J. L., and A. Schwitalla. 2008. Archaeological perspectives on the effects of medieval drought in prehistoric California. Quaternary International 188(1):41-58.

Keeley, J. E. 2005. Fire history of the San Francisco East Bay region and implications for landscape patterns. International Journal of Wildland Fire 14:285-296.

Keeley, J. E. 2002. Native American impacts on fire regimes of the California coastal ranges. Journal of Biogeography 29(3):303-320.

Kroeber, A. L. 1925. Handbook of the Indians of California. Bureau of American Ethnology Bulletin 78. Smithsonian Institute, Washington, D.C., USA.

Kroeber, A. L., and S. A. Barrett. 1960. Fishing Among the Indians of Northwestern California. Pages 1-210 in J. H. Rowe, R. F. Heizer, R. F. Murphy, and E. Norbeck, editors. Anthropological Records, Volume 21, Number 1. University of California Press, Berkely, CA, USA.

Lake, F. K. 2013. Historical and cultural fires, tribal management and research issues in Northern California: trails, fires, and tribulations. Occasion: Interdisciplinary Studies in the Humanities 5:1-22.

Lake, F. K., V. Wright, P. Morgan, M. McFadzen, D. McWethy, and C. Stevens-Rumann. 2017. Returning fire to the land: celebrating traditional knowledge and fire. Journal of Forestry 115(5):343-353.

Larson, S., R. Jameson, M. Etnier, T. Jones, and R. Hall. 2012. Genetic diversity and population parameters of sea otters, Enhydra lutris, before fur trade extirpation from 1741-1911. PLoS ONE 7(3):e32205.

Lightfoot, K. G. 1993. Long-term developments in complex hunter-gatherer societies: recent perspectives from the Pacific Coast of North America. Journal of Archaeological Research 1(3):167-201.

Lightfoot, K. G., and E. M. Luby. 2002. Late Holocene in the San Francisco Bay area: temporal trends in the use and abandonment of shell mounds in the East Bay. Pages 263-281 in J. Erlandson, T. L. Jones, and J. E. Arnold, editors. Catalysts to Complexity: Late Holocene Societies of the California Coast. Cotsen Institute of Archaeology, Los Angeles, CA, USA.

Lightfoot, K. G., and O. Parrish. 2009. California Indians and Their Environment: An In- 
troduction. University of California Press, Oakland, CA, USA.

Lindsay, B. C. 2015. Murder State: California's Native American Genocide, 1846-1873. University of Nebraska Press, Lincoln, NE, USA.

Lone, K., L. E. Loe, E. L. Meisingset, I. Stamnes, and A. Mysterud. 2015. An adaptive behavioural response to hunting: surviving male red deer shift habitat at the onset of the hunting season. Animal Behaviour 102:127-138.

Luby, E. M., C. D. Drescher, and K. G. Lightfoot. 2006. Shell mounds and mounded landscapes in the San Francisco Bay area: an integrated approach. Journal of Island and Coastal Archaeology 1(2):191-214.

MacArthur, R. H., and E. R. Pianka. 1966. On optimal use of a patchy environment. The American Naturalist 100(916):603-609.

Madley, B. 2017. An American Genocide: The United States and the California Indian Catastrophe, 1846-1873. Yale University Press, New Haven, CT, USA.

Magura, T., and G. L. Lövei. 2020. The Permeability of Natural versus Anthropogenic Forest Edges Modulates the Abundance of Ground Beetles of Different Dispersal Power and Habitat Affinity. Diversity 12:320.

Malhi, Y., C. E. Doughty, M. Galetti, F. A. Smith, J.-C. Svenning, and J. W. Terborgh. 2016. Megafauna and ecosystem function from the Pleistocene to the Anthropocene. Proceedings of the National Academy of Sciences 113:838-846.

Marantz, S. A., J. A. Long, S. L. Webb, K. L. Gee, A. R. Little, and S. Demarais. 2016. Impacts of human hunting on spatial behavior of white-tailed deer (Odocoileus virginianus) Canadian Journal of Zoology 94:853-861.

Marlon, J. R., P. J. Bartlein, D. G. Gavin, C. J. Long, R. S. Anderson, C. E. Briles, K. J. Brown, D. Colombaroli, D. J. Hallett, M. J. Power, E. A. Scharf, and M. K. Walsh. 2012. Long-term perspective on wildfires in the western USA. Proceedings of the National Academy of Sciences 109:E535-E543.

Meko, D. M., M. D. Therrell, C. H. Baisan, and M. K. Hughes. 2001. Sacramento River flow reconstructed to A.D. 869 from Three Rings. Journal of the American Water Resources Association 37(4):1029-1039.

Meyer, J., and J. S. Rosenthal. 2008. Cultural resources inventory of Caltrans District 3 rural conventional highways: a geoarchaeological overview and assessment of Caltrans District 3. California Department of Transportation, District 3, Marysville, CA, USA.

Meyer, J., and J. S. Rosenthal. 1997. Archaeological and geoarchaeological investigations at eight prehistoric sites in the Los Vaqueros Reservoir Area, Contra Costa County, California. Anthropological Studies Center, Sonoma State University, Santa Rosa, CA, USA.

Milliken, R., L. H. Shoup, and B. R. Ortiz. 2009. Ohlone/Costanoan Indians of the San Francisco Peninsula and their Neighbors, Yesterday and Today (Response to Solicitation No. Q8158020405). National Park Service, Golden State National Recreation Area, San Francisco, CA, USA.

Milliken, R., R. T. Fitzgerald, M. G. Hylkema, R. Groza, T. Origer, D. G. Bieling, A. Leventhal, R. S. Wiberg, A. Gottsfield, D. Gillette, V. Bellifemine, E. Strother, R. Cartier, and D. A. Fredrickson. 2007. Punctuated culture change in the San Francisco Bay area. Pages 99-124 in T. L. Jones and K. A. Klar, editors. California Prehistory Colonization, Culture, and Complexity. AltaMira Press, Lanham, MD, 
USA.

Miszaniec, J. I., J. W. Eerkens, and E. J. Bartelink. 2018. An icthyoarchaeological study of dietary change in the California Delta, Contra Costa County. Proceedings of the Society for California Archaeology 32:269-278.

Moratto, M. J. 1984. California Archaeology. Academic Press, Orlando, FL, USA.

Moyle, P. B. 2002. Inland Fishes of California. University of California Press, Berkeley, CA, USA.

Odling-Smee, J., D. H. Erwin, E. P. Palkovacs, M. W. Feldman, and K. N. Laland. 2013. Niche construction theory: a practical guide for ecologists. The Quarterly Review of Biology 88(1):3-28.

Odling-Smee, J. F., K. N. Laland, and M. W. Feldman. 2003. Niche Construction: The Neglected Process in Evolution. Princeton University Press, Princeton University, NJ, USA.

Papworth, S. K., J. Rist, L. Coad, and E. J. Milner-Gulland. 2009. Evidence for shifting baseline syndrome in conservation. Conservation Letters 2:93-100.

Paton, D. G., S. Ciuti, M. Quinn, and M. S. Boyce. 2017 Hunting exacerbates the response to human disturbance in large herbivores while migrating through a road network. Ecosphere 8(6):1841.

Pilloud, M. A. 2006. The impact of the medieval climatic anomaly in prehistoric California: a case study from Canyon Oaks, CA-ALA-613/H. Journal of California and Great Basin Anthropology 26(2):179-192.

Pollack, O, and T. Kan. 1998. The use of prescribed fire to control invasive exotic weeds at Jepson Prairie Preserve. Pages 241-249 in C. W. Witham, E. T. Bauder, D. Belk, W. R. Ferren, Jr., and R. Ornduff, editors. Ecology, Conservation, and Management of Vernal Pool Ecosystems - Proceedings from 1996 conference. California Native Plant Society, Sacramento, CA, USA.

Preston, W. 1997. Serpent in the garden: environmental change in colonial California. California History 76(2-3):260-298.

Preston, W. L. 2002. Portents of plague from California's Protohistoric Period. Ethnohistory 49(1):69-121.

Prince-Buitenhuys, J. R., and E. J. Bartelink. 2020. Niche construction theory in bioarchaeology. Pages 93-112 in C. M. Cheverko, J. R. Prince-Buitenhuys, and M. Hubbe, editors. Theoretical Approaches in Bioarchaeology. Routledge, Abingdon, VA, USA.

Rick, T. C., and R. Lockwood. 2013. Integrating paleobiology, archeology, and history to inform biological conservation: paleobiology, archeology, and history. Conservation Biology 27:45-54.

Riede, F. 2019. Niche construction theory and human biocultural evolution. Pages 337 358 in A. M. Prentiss, editor. Handbook of Evolutionary Research in Archaeology. Springer, Cham, Switzerland.

Rodrigues, A. S. L., S. Monsarrat, A. Charpentier, T. M. Brooks, M. Hoffmann, R. Reeves, M. L. D. Palomares, and S. T. Turvey. 2019. Unshifting the baseline: A framework for documenting historical population changes and assessing long-term anthropogenic impacts. Philosophical Transactions of the Royal Society B: Biological Sciences 374:20190220.

Rosenthal, J. S., and K. R. McGuire. 2004. Middle Holocene Adaptations in the Central Si- 
erra Foothills: Data Recovery Excavations at the Black Creek Site, CA-CAL-789. Far Western Anthropological Research Group, Inc., Davis, CA. Submitted to California Department of Transportation, District 6, Fresno, CA, USA.

Rosenthal, J. S., G. G. White, and M. Q. Sutton. 2007. The Central Valley: a view from the catbird's seat. Pages 147-164 in T. L. Jones and K. A. Klar, editors. California Prehistory Colonization, Culture, and Complexity. AltaMira Press, Lanham, MD, USA.

Rougle, W. 2019. Reducing barriers to prescribed fire on private lands in California. Thesis, California State University, Chico, CA, USA.

Sáenz-Arroyo, A., C. Roberts, J. Torre, M. Cariño-Olvera, and R. Enríquez-Andrade. 2005. Rapidly shifting environmental baselines among fishers of the Gulf of California. Proceedings of the Royal Society B: Biological Sciences 272:1957-1962.

San Francisco Estuary Institute. 2008. Land use history. Pages 13-37 in South Santa Clara Valley Historical Ecology Study. Santa Clara Valley Water District and the Nature Conservancy. Available from: https://www.sfei.org/SouthStaClaraValleyHEStudy

Sandos, J. A. 2008. Converting California: Indians and Franciscans in the Missions. Yale University Press, New Haven, CT, USA.

Scharf, E. A. 2014. Deep time: the emerging role of archaeology in landscape ecology. Landscape Ecology 29:563-569.

Schenck, W. E., and E. J. Dawson. 1929. Archaeology of the northern San Joaquin Valley. University of California Publications of American Archaeology and Ethnology 25(4):289-413.

Schoener, T. W. 1971. Theory of feeding strategies. Annual Review of Ecology and Systematics 2(1):369-404.

Schwitalla, A., and J. L. Jones. 2012. A land of many seasons: bioarchaeology and the Medieval Climatic Anomaly hypothesis in central California. Pages 93-114 in T. L. Jones and J. E. Perry, editors. Contemporary Issues in California Archaeology. Routledge, New York, NY, USA.

Schulz, P. D. 1979. Fish remains from a historic central California Indian village. California Fish and Game 65:273-276.

Schulz, P. D., and D. D. Simmons. 1973. Fish species diversity in a prehistoric central California midden. California Fish and Game 59:107-113.

Soga, M., and K. J. Gaston. 2018. Shifting baseline syndrome: causes, consequences, and implications. Frontiers in Ecology and the Environment 16(4):222-230.

Sowerwine, J., D. Sarna-Wojcicki, M. Mucioki, L. Hillman, F. Lake, and E. Friedman. 2019a. Enhancing food sovereignty: a five-year collaborative tribal-university research and extension project in California and Oregon. Journal of Agriculture, Food Systems, and Community Development 9(2):167-190.

Sowerwine, J., M. Mucioki, D. Sarna-Wojcicki, and L. Hillman. 2019b. Reframing food security by and for Native American communities: a case study among tribes in the Klamath River basin of Oregon and California. Food Security 11(3):579-607.

Starr, K. 1980. California! Peregrine Smith Books, Layton, UT, USA.

Stephens, S. L., B. M. Collins, C. J. Fettig, M. A. Finney, C. M. Hoffman, E. E. Knapp, M. P. North, H. Safford, and R. B. Wayman. 2018. Drought, tree mortality, and wildfire in forests adapted to frequent fire. BioScience 68:77-88.

Stewart, B. P., A. T. Nelson, K. Laberee, S. E. Nielsen, M. A. Wulder, and G. Stenhouse. 
2013. Quantifying grizzly bear selection of natural and anthropogenic edges. Journal of Wildlife Management 77:957-964.

Suarez-Esteban, A., L. Fahrig, M. Delibes, and J. M. Fedriani. 2016. Can anthropogenic linear gaps increase plant abundance and diversity? Landscape Ecology 31:721729

Sundahl, E. 1982. The Shasta Complex in the Redding Area, California. Thesis, California State University, Chico, CA, USA.

Testart, A. 1982. The significance of food storage among hunter-gatherers: residence patterns, population densities, and social inequalities. Current Anthropology 23:523537.

Turvey, S. T., editor. 2009. Holocene Extinctions. Oxford University Press, Oxford, UK.

U.S. Fish and Wildlife Service (USFWS). 2017. Recovery plan for the giant garter snake (Thamnophis gigas). Pacific Southwest Region, Sacramento, CA, USA.

Whitaker, A. R., J. S. Rosenthal, and P. Brandy. 2019. Social boundaries, territoriality, and the cultural ecology of artiodactyl hunting in prehistoric central California. Quaternary International 518:83-98.

White, G. G. 2003a. Population ecology of the prehistoric Colusa Reach. Dissertation, University of California, Davis, CA, USA.

White, G. G. 2003b. Testing and mitigation at four sites on level (3) long haul fiber optic alignment, Colusa County, California. Prepared for Kiewit Pacific, Concord. Archaeological Research Program, California State University, Chico. CA, USA.

Wiberg, R. S. 2010. Archaeological investigations at CA-CCO-18/548. Final report for the vineyards at Marsh Creek Project, Contra Costa County, California. Report on file at Holman and Associates, San Francisco, CA, USA.

Wires, K. N., and J. LaRose. 2019. Sogorea Te' Land Trust and indigenous food sovereignty in the San Francisco Bay area. Journal of Agriculture, Food Systems, and Community Development 9(2):31-34.

Wohlgemuth, E. 1996. Resource intensification in prehistoric central California: evidence from archaeobotanical data. Journal of California and Great Basin Anthropology 18(1):81-103.

Wohlgemuth, E. 1997. Plant Remains. Appendix H in J. Meyer and J. S. Rosenthal, editors. Archaeological and Geoarchaeological Investigations at Eight Prehistoric Sites in the Los Vaqueros Reservoir Area, Contra Costa County, California. Anthropological Studies Center, Sonoma State University, Santa Rosa, CA, USA.

Wohlgemuth, E. 2004. The course of plant food intensification in native central California. Dissertation, University of California, Davis, CA, USA.

Wohlgemuth, E. 2016. Early limits to the central California acorn economy in the lower Sacramento Valley. Journal of California and Great Basin Anthropology 36(2):181-192.

Wolverton, S., and R. L. Lyman. 2012. Conservation Biology and Applied Zooarchaeology. University of Arizona Press, Tucson, AZ, USA.

Yoshiyama, R. M., E. R. Gerstung, F. W. Fisher, and P. B. Moyle. 2001. Historical and present distribution of Chinook salmon in the Central Valley drainage of California. Fish Bulletin 179(1):71-176.

Yoshiyama, R. M., F. W. Fisher, and P. B. Moyle. 1998. Historical abundance and decline of chinook salmon in the Central Valley region of California. North American 
Journal of Fisheries Management 18(3):487-521.

Zuckerman, M. K., and D. L. Martin. 2016. Introduction: the development of biocultural perspectives in anthropology. Pages 7-26 in M. K. Zuckerman and D. L. Martin, editors. New Directions in Biocultural Anthropology. John Wiley \& Sons, Hoboken, NJ, USA.

Submitted 10 January 2021

Accepted 25 March 2021

Associate Editor was A. Baker 